This table brings out very clearly the large size of the provincial ophthalmic hospitals. Somewhat to one's surprise it shows that the Manchester Royal Eye Hospital is the largest eye hospital in Great Britain and possibly in the world.

Someone might object to this statement and say that with eye hospitals the number of new out-patients seen during the course of the year is a better criterion of efficiency than the number of beds available for in-patients.

Hospitals, however, have always been measured by their bed strength and not by the number of patients seen.

I have omitted the figures of my own hospital the Royal Westminster Ophthalmic Hospital and also those of the Western Ophthalmic Hospital as both of these institutions have been in the throes of rebuilding and have not been fully open the whole period, consequently their figures are not normal.

The table brings out the fine average of beds kept constantly full enjoyed by Moorfields.

It also shows the more generous in-patient treatment as compared to the number of out-patients which is enjoyed by the Manchester citizen.

Yours faithfully,

Adrian Caddy.

LONDON,

March, 1930.

\title{
"LEAH, TENDER OR SORE-EYED"
}

To the Editor of The British Journal of Ophthalmology.

SIR,-The subject of Leah's eyes referred to in a note in the journal for April (p. 190) is one that presents considerable difficulty to Bible scholars. In the original Hebrew Leah's eyes are described as being $ת i \supseteq า$ and this adjective has had a wide variety of interpretations, as can be seen from the different meaning attached to it in the standard translations.

The reading of tender-eyed in the authorised version is supported by the French version in the Hexaglot Bible: "Mais Léa avait les yeux tendres, et Rachel était de belle taille et belle à voir." The authorised German version, on the other hand, agrees with the Septuagint in regarding Leah as weak-sighted. "A Aber Lea hatte ein blödes Gesicht, Rachel war hübsch und schön." The septua-

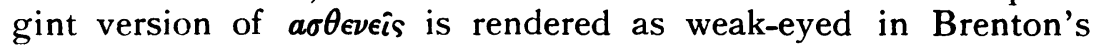
translation: "And the eyes of Leah were weak. But Rachel was beautiful and exceedingly fair in countenance," but it must be 
remembered that in the New Testament a $\sigma \theta \epsilon \nu \epsilon \hat{s}$ often stands for sick (e.g., Matthew, xxv, 39, 43, 44; Luke x, 9, etc.). From these various translations it is therefore possible to regard Leah as being the possessor of eyes that were either tender, weak or sick. It cannot be argued that the original Hebrew implies disease, for the adjective does not appear to be used in this sense anywhere. In Genesis xxxiii, 13, it is used to imply tender " My Lord knoweth that the children are tender, and the flocks and herds with young are with me : and if men should overdrive them one day, all the flock will die." Elsewhere (II Samuel, iii, 39) the listlessness of exhaustion rather than sickness is implied, especially as the contrast of hardness is used: "And I am this day weak, though annointed king, and those men . . . be too hard for me." Weakness in the metaphorical sense is implied in Deuteronomy $\mathbf{x x}, 8$, where fainthearted is the translation used: "What man is there that is fearful and fainthearted, let him go and return to his house."

John Skinner in his commentary on Genesis (The International Critical Commentary: Genesis, p. 383) holds that Leah's eyes lacked in the lustrous brilliancy which is accounted a feature of female beauty in the East. A similar view is expressed by Knobel, who points out that among "Oriental peoples and especially amongst Arabs, vivacious, fiery, clear and expressive black eyes, which they love to compare to the eyes of the gazelle, are considered as the most important feature of feminine beauty " (quoted by L. Kotelmann, Die Ophthalmologie bei den Alten Hebräern, 1910, p. 144).

Such a view has much to commend it. The preoccupation with the eye in the scheme of beauty of oriental nations is well illustrated by that epic of oriental passion, the "Song of Songs " " Behold thou art fair, my love ; behold thou art fair ; thou hast dove's eyes." " Thou has ravished my heart with one of thine eyes "). And in the paradise of the Koran damsels with black eyes figure prominently. It must also be remembered that the eye shares with the heart the popular fancy of having all sort of charms and virtues ascribed to it ; and just as it is unwise to assume vascular sclerosis when the Bible speaks of a hard heart, or myocardial flabbiness when the softhearted are discussed, so it is unsafe to assume organic ocular disease when there is a vague reference to weak eyes. Unless there is strong reason to the contrary, it is a safe rule to regard all references appearing in non-technical literature and bearing on the eye or heart, as being purely metaphorical. One Jewish commentator (Raschi) holds that Leah's eyes were weak from weeping, and that she wept because she feared she would have to marry Esau instead of Jacob. Here is a rather pathetic case of weak eyes due to a broken heart. 
One curious piece of evidence rather goes against the metaphorical theory. In Yiddish Leah's eyes have a proverbial significance, which is used to imply any disfigurement affecting the eyes. It should be interesting to know the antiquity of this proverbial usage.

Yours faithfully,

X.Y.Z.

\section{NOTES}

The William

Mackenzie Medal, 1929.

The William Mackenzie medal for outstanding contributions to ophthalmology in 1929 has been awarded to Professor J. van der Hoeve,

of Leiden, Holland.

The Oxford Ophthalmological

Congress, 1930.

THE Twentieth Annual Meeting of the Oxford Ophthalmological Congress will be held at Oxford on July 9 to 12,1930 . The following preliminary arrangements have been made:-July 10, in the morning, Symposium on "Toxic Amblyopia," to be introduced by Dr. H. M. Traquair ; Sir E. Farquhar Buzzard, Bart., K.C.V.O., Regius Professor of Physic in the University ; and Dr. J. A. Gunn, Professor of Pharmacology at the University. On the afternoon of the same day Sir Oliver Lodge will give an address entitled "Modern Theories on the Nature of Light." The Doyne Memorial Lecture will be delivered on the morning of July 11, by Dr. Harry Friedenwald, of Baltimore; the subject being " Pathological Changes in the Retinal Blood Vessels and their Significance." An address will be given by Professor Arthur Schüller, of Vienna, on "Recent Developments in Radiology associated with Ophthalmology." An address will also be given by Professor Jules Gonin, of Lausanne, on " Detachment of the Retina and its Treatment." In addition the following have promised papers :Dr. Leighton Davies, Dr. Bernard Samuels, of New York, Dr. de Courcy, of Liverpool, and Dr. J. A. van Heuven, of Utrecht. The Friedenwald ophthalmoscope will be demonstrated. The Annual Dinner will be held in Keble College Hall on July 10. The Hon. Secretary of the Congress is Mr. C. G. Russ Wood, of Shrewsbury.

Appointments.

Mr. L. H. Savin has been appointed Ophthalmic Surgeon to the Metropolitan Hospital.

Dr. E. V. Srinivasan has been appointed Hon. Ophthalmic Surgeon to the Government Royapettah Hospital, Madras. 